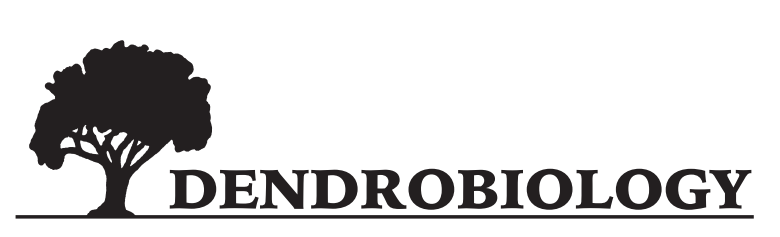

2017, vol. 77, 161-175

http://dx.doi.org/10.12657/denbio.077.013

\author{
Zdeněk Vacek, Stanislav Vacek, Daniel Bulušek, Vilém Podrázský, \\ Jiři Remeš", Jan Král, Tereza Putalová
}

\title{
Effect of fungal pathogens and climatic factors on production, biodiversity and health status of ash mountain forests
}

Received: 9 March 2016; Accepted: 11 January 2017

\begin{abstract}
European ash (Fraxinus excelsior L.) is a broad-leaved fast-growing tree species common in most parts of Europe, highly-valued for its ecological properties and occurrence in many forest site types. Its future is threatened, especially by an invasive fungal pathogen Hymenoscyphus fraxineus causing disintegration of E. ash stands throughout all Europe. This paper deals with changes in stand structure, biodiversity and production parameters in mixed European ash stands in the Krkonoše Mountains National park, Czech Republic, with respect to ash dieback progress for period 2009-2015. Studied four permanent research plots ( $0.25 \mathrm{ha})$ showed negative dynamics of stand structural and production parameters. Volume of ash ranged between $98-376 \mathrm{~m}^{3} \mathrm{ha}^{-1}$ (stand volume $378-613 \mathrm{~m}^{3} \mathrm{ha}^{-1}$ ), which indicates a decrease by $2.7 \%$ during 6 years. Detected fungi caused mean deterioration of foliage by $22.9 \%$, canopy by $15.8 \%$ and mortality reached $15.2 \%$. The earlier ash dieback symptoms were detected at suppressed and intermediate trees, especially on waterlogged sites and at low altitude. Conversely, ash dieback was reflected less intensively at higher-elevated sloping stands, although low temperature (particularly severe frosts at the beginning of the year) was prevailing limiting factor for radial growth of ash in these mountain areas. The biodiversity indices of tree layer indicate mostly medium values with a decreasing tendency (to $22.4 \%$ ). Relationship between spatial pattern of trees without dieback symptoms and infected trees was positive at small distances (to $7 \mathrm{~m}$ ) or random. In terms of preventive silvicultural practices, strong systematic thinning is recommended to maintain the vitality of ash stands.
\end{abstract}

Keywords: Fraxinus excelsior, ash dieback, stand structure, dynamics, Central Europe

Addresses: Z. Vacek, S. Vacek, D. Bulušek, V. Podrázský, J. Remeš, J. Král, T. Putalová, Czech University of Life Sciences Prague, Faculty of Forestry and Wood Sciences, Kamýcká 129, 16521 Prague 6 - Suchdol, Czech Republic, e-mail: remesj@email.cz

\section{Introduction}

European ash (Fraxinus excelsior L.) is an important tree species in Europe and a great part of Asia (Kerr \& Cahalan, 2004; Fraxigen, 2005; Tollefsrud et al., 2016). Fraxinus is a flexible genus which can be found over a wide range of growing conditions from coastal to mountainous regions, especially on steep slopes (Stöhr \& Lösch, 2004), from pioneer to mature woodland, from nutrient-rich to poorer soils 
(Ferrazzini et al., 2007; Dufour \& Piégay, 2008). Its drought tolerance and frost sensitivity would have made ash a tree species potentially favored by the expected climate warming and drying (Scherrer et al., 2011).

In forest ecosystems, ash occurs mainly as an admixed species in various forest communities, but rarely attains dominance (Ellenberg, 2010). Unlike most temperate zone tree species, the ash tree requires soils rich in nitrogen and exchangeable bases (Hofmeister et al., 2004). Its growth is also stimulated by phosphorus (Weber-Blaschke et al., 2008). Ash expansion, especially in lower altitudes in Europe, is often attributed to higher nitrogen deposits (Bobbink et al., 1998; Hofmeister et al., 2004); no relevant studies for higher altitudes are available.

In central European submontane and lower montane regions, ash grows mainly in mixed alluvial stands together with alder - Carici remotae-Fraxinetum (Neuhäuslová \& Káňa, 1999; Matuszkiewicz, 2008). Temperate zone alluvial forests are often characterized by rich phytocoenoses of high structural diversity (Szymura et al., 2010). In even-aged pure ash stands, high density of the stand is difficult to maintain (Le Goff et al., 2011), though there were exceptions in the past (Duval, 1987). In the European system of "Natura 2000", mixed ash alluvial stands are considered to be very important biotopes requiring close attention (Kenderes et al., 2008; Chytrý et al., 2010).

It is important to mention problems threatening stands with ash in the long-term view of their spontaneous development. In the past, only sporadic and locally infections of ash were caused by common viral and fungal leaf diseases and pathogens causing the cancer formation particular by Nectria fungus, and bacteria of the genus Pseudomonas (Nárovec et al., 2008). At present ash is significantly compromised by many threats (Dobrowolska et al., 2011). It has been documented that long-lasting influence of browsing might prevent ash from natural regeneration (Schröder \& Dujesiefken, 2001; Szymura et al., 2010). In the Czech Republic, Čermák \& Mrkva (2006) found out that browsing was the primary reason of a decrease in ash natural regeneration density and height. In Europe, the most important threat is pathogenic fungus Hymenoscyphus fraxineus (T. Kowalski) Baral, Queloz, Hosoya, comb. nov. (Kowalski, 2006; Bakys et al., 2009; Skovsgaard et al., 2010; Pautasso et al., 2013; Adamčíková et al., 2015), which spread after its first documenting in Poland throughout the central, northern and western Europe since 1990-ies (Dal Maso \& Montecchio, 2014; McKinney et al., 2014), causing considerable ash dieback and mortality (Orlikowski et al., 2011). The rate of dispersion through the air can reach up to $30 \mathrm{~km} \mathrm{y}^{-1}$ (Solheim et al., 2011) and young infected trees can die during one growing season (Havrdová \& Černý, 2013), older then during several years (Bakys et al., 2009; Enderle et al., 2013). Some study even argued that whole ash populations might collapse (McKinney et al., 2011). Nevertheless, high economic as well as ecological value of the species and of its timber challenges the reintroduction of this species in the forest stands (Goberville et al., 2016). Ash decline affects many other plant and animal species linked with it (Rackham et al., 2014; Landolt et al., 2016).

Infected ash trees are present on a massive scale across a broad range of stands (Timmermann et al., 2011; Jönsson \& Thor, 2012), this is considered as a result of interaction between climatic changes and pathogens (Matisons et al., 2016). Ash dieback depends on habitat site, stand conditions and climatic factors (precipitation, temperature) (Kowalski, 2006; Bakys et al., 2009; Dobrowolska et al., 2011; Kowalski, 2016). Infection by $H$. fraxineus is strongly influenced by air and soil humidity (Kirisits, 2012; Havrdová et al., 2014). Interactions between fungal pathogen and host tree are particularly important in relation to global climatic changes, with respect to reproduction, distribution and survival (Kowalski, 2016). Ash dieback is also closely connected with silvicultural practices, such as thinning of suppress trees susceptible to diseases and infected trees, suitable changes of tree species composition, selection of resistant genotypes and others (Dobrowolska et al., 2011; Skovsgaard, 2013; Havrdová et al., 2014, 2016).

Properties favoring the ash in comparison with other tree species of a climax forest (Korpel, 1995) are e.g. almost annual fructification of seeds easily dispersible by wind (Mitchell, 1974), or fast growth at young age (Szymura et al., 2010). Successful growth is also supported by the architecture of the ash crown canopy (Marigo et al., 2000; Kerr \& Cahalan, 2004). Next, ash leaf litter is phytotoxic and might limit the growth of other plants (Dobrowolska et al., 2011).

The objective of the presented research was to evaluate effect of fungal pathogens and climatic factors on production, biodiversity and health condition of ash mountain forest stands in the Krkonoše National Park, Czech Republic. The particular aims were to determine 1) changes in structure, growth parameters, biodiversity and health status (foliation) of European ash stands with ash dieback in period 2009-2015; 2) differences in damage/resistence to $H$. Fraxineus in respect to site parameters (humidity, altitude, slope) and stand characteristic (tree layers, structure, species composition); 3) effect of precipitation and temperature on radial increment of ash; 4) possible silvicultural principles and preventive treatments to reduce ash dieback. 


\section{Materials and methods}

\section{Characteristics of study area}

The study was carried out in four permanent research plots (PRPs) with European ash in the eastern part of the Krkonoše National Park, with altitude gradient 540-860 m a.s.l. (Fig. 1). The Krkonoše National Park was declared in 1963 on the Czech-Polish border in Krkonoše Mts. (synonymous Giant Mts.) and in 1992 was included as a bilateral Biosphere Reserve. The parent rock of this park is formed mainly by granite, mica schist and phyllite. At the lowest altitudes, the predominant soil types are Cambisols, above $1,000 \mathrm{~m}$ a.s.l. Podzols and in the proximity of numerous water springs in mosaic with Gleysols. Average precipitation varies with respect to altitude from $650 \mathrm{~mm}$ to $1260 \mathrm{~mm}$ and mean annual temperature decreases with altitude from $7.6{ }^{\circ} \mathrm{C}$ to $2.6{ }^{\circ} \mathrm{C}$. Selection of four PRPs represents a combination of high and low altitudes and high and low soil moisture (Tab. 1).

\section{Data collection}

To determine the tree layer structure, four PRPs of $50 \times 50 \mathrm{~m}(0.25 \mathrm{ha})$ were established in 2009. All

Table 1. Overview of basic site characteristics of permanent research plots

\begin{tabular}{|c|c|c|c|c|c|c|c|c|c|}
\hline PRP & GPS coordinates & $\begin{array}{l}\text { Altitude } \\
(\mathrm{m})\end{array}$ & $\begin{array}{l}\text { Grow. } \\
\text { season }\end{array}$ & Temper. ${ }^{1}\left({ }^{\circ} \mathrm{C}\right)$ & $\begin{array}{c}\text { Precipit. }^{1} \\
(\mathrm{~mm})\end{array}$ & Soil type & $\begin{array}{c}\text { Expo-si- } \\
\text { tion }\end{array}$ & Slope $\left(^{\circ}\right)$ & $\begin{array}{c}\text { Forest site } \\
\text { type }^{2}\end{array}$ \\
\hline 39 & $\begin{array}{l}50^{\circ} 39^{\prime} 03^{\prime \prime} \mathrm{N} \\
15^{\circ} 53^{\prime} 19^{\prime \prime} \mathrm{E}\end{array}$ & 650 & 124 & $6.8 / 12.8$ & $880 / 640$ & $\begin{array}{c}\text { Histic } \\
\text { Gleysols }\end{array}$ & NE & 14 & $5 \mathrm{~V}$ \\
\hline 40 & $\begin{array}{l}50^{\circ} 37^{\prime} 08^{\prime \prime} \mathrm{N} \\
15^{\circ} 51^{\prime} 01^{\prime \prime} \mathrm{E}\end{array}$ & 540 & 130 & $7.6 / 13.9$ & $830 / 610$ & $\begin{array}{l}\text { Modal Cam- } \\
\text { bisols }\end{array}$ & SW & 4 & $5 \mathrm{D}$ \\
\hline 42 & $\begin{array}{l}50^{\circ} 42^{\prime} 30^{\prime \prime} \mathrm{N} \\
15^{\circ} 50^{\prime} 01^{\prime \prime} \mathrm{E}\end{array}$ & 850 & 115 & $5.2 / 10.8$ & $1080 / 660$ & $\begin{array}{l}\text { Gleyic Cam- } \\
\text { bisols }\end{array}$ & SE & 24 & $6 \mathrm{D}$ \\
\hline 60 & $\begin{array}{l}50^{\circ} 39^{\prime} 51^{\prime \prime} \mathrm{N} \\
15^{\circ} 51^{\prime} 07^{\prime \prime} \mathrm{E}\end{array}$ & 860 & 111 & $4.9 / 10.1$ & $1040 / 650$ & $\begin{array}{l}\text { Gleyic Cam- } \\
\text { bisols }\end{array}$ & $\mathrm{NE}$ & 16 & $6 \mathrm{D} / 6 \mathrm{~V}$ \\
\hline
\end{tabular}

Notes: ${ }^{1}$ mean value during all year/in growing season; ${ }^{2} 5 \mathrm{~V}$ and $6 \mathrm{~V}$ brook and spring alder zone of the suballiance Alnenion glutinoso-incanae Oberdorfer 1953, 5D and 6D represent vegetation associations of Pruno padi-Fraxinetum excelsioris Oberdorfer 1953 and Mercuriali perennis-Fraxinetum excelsioris Klika 1941.

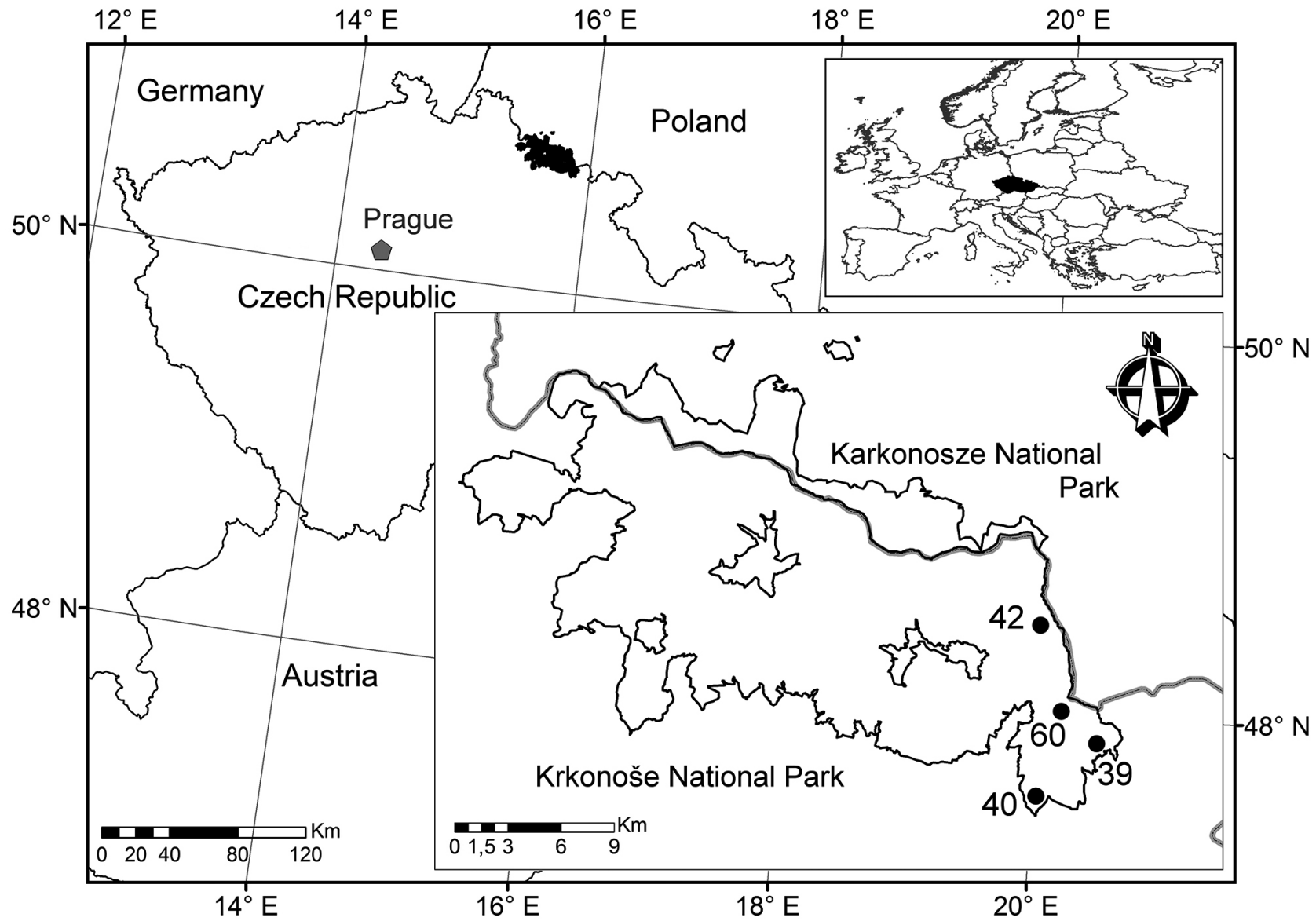

Fig. 1. Localization of the studied permanent research plots with European ash in the Krkonoše Mts. 
individuals with breast height diameter $(\mathrm{DBH})>5$ $\mathrm{cm}$ and their crown projections were located. Crown perimeter was measured at least at four directions perpendicular to each other. $\mathrm{DBH}$, height and base of live crown were measured in all trees. DBH of the tree layer were measured with a calliper (accuracy $1 \mathrm{~mm}$ ) while tree heights and crown heights were measured with a Vertex laser hypsometer (accuracy $0.1 \mathrm{~m}$ ). These measurements were repeated in 2015 using the Field-Map technology (IFER-Monitoring and Mapping Solutions Ltd).

On each PRP, increment cores were taken from 30 dominant and co-dominant trees at breast height, perpendicular to the stem axis, up and down the slope, using Pressler auger. Tree-ring widths were measured to the nearest $0.01 \mathrm{~mm}$ with an Olympus stereo microscope on a LINTAB measurement table and recorded by the TSAPWIN software (RESISTOGRAPH).

In 2009-2015, the health dynamics of mixed stands on four PRPs in the Krkonoše National Park, with the accent on European ash, was annually evaluated by foliage status of individual trees, scaled into degrees of defoliation. Average foliage of the stand is expressed as arithmetical mean of foliage values of all PRP trees and live trees (cf. Vacek et al., 2015). Defoliation (complement to foliage to $100 \%$ ), with special regard to coenotic/social position and morphological type of crown, was estimated with the accuracy of $5 \%$ and recorded using 6 degrees of defoliation, corresponding with the degrees of tree damage. This methodology is almost the same as in the international project ICP-Forests and ICP Focus (Lorenz, 1995).

To determine the cause of ash dieback, five affected shoot cuttings were taken in May 2015 from all PRPs. Mycological analysis confirmed $H$. fraxineus (following the methods of Kowalski, 2006) as the main causal agent of the current epidemic of ash dieback. The pathogenic fungus was determined in all 20 samples collected in this study. Other isolated fungi included Diplodia mutila, Valsa cypri and Diaporthe eres.

\section{Data analysis}

In all individuals of the tree layer on each plot, structural and growth parameters, quantity of production, structural diversity (horizontal and vertical), trees species diversity and total stand diversity were evaluated due to the determination of stand characteristics and its dynamics after ash dieback. The tree volume was calculated by volume equations published by Petráš \& Pajtík (1991).

For tree species diversity, following indicators were evaluated: species richness $D$ (Margalef, 1958), species heterogeneity $H^{\prime}$ (Shannon, 1948) and species evenness E (Pielou, 1975). Structural and total diversity was evaluated by these indices (Tab. 2): Arten-profil index $A$ (Pretzsch, 2006), diameter $T M_{d}$ and height differentiation index $T M_{h}$ (Füldner, 1995), index of non-randomness $\alpha$ (Mountford, 1961), aggregation index $R$ (Clark \& Evans, 1954) and total diversity index $B$ (Jaehne \& Dohrenbusch, 1997).

Characteristics describing horizontal structure of individuals on the plot were calculated using PointPro 2.2 ( 2010 Zahradnik \& Pus). The test of deviations significance against values expected for random layout of points was carried out by Monte Carlo simulation. Medium values of the $L$ - function were estimated from 1999 randomly generated point structures. The relationship between spatial pattern of ash trees without dieback symptoms and trees infected by $H$. fraxineus were calculated by software $\mathrm{R}$ 3.1. ( 2014 The R Foundation) by pair cross correlation function (Stoyan \& Stoyan, 1992). Moreover, the stand density (SDI), crown closure and crown projection areas was calculated. Layout maps were created in the program ArcGIS (c) 1999-2010 Esri).

To determine the influence of climatic factors and ash dieback on the radial growth of trees, the annual ring increment series (used 112 trees) were

Table 2. Overview of indices describing the stand structure and their common interpretation

\begin{tabular}{|c|c|c|c|c|}
\hline Criterion & Quantifiers & Label & Reference & Evaluation \\
\hline \multirow[t]{3}{*}{ Species diversity } & Richness & $D$ & Margalef, 1958 & minimum $D=0$, higher $D=$ higher values \\
\hline & Heterogeneity & $H^{\prime}$ & Shannon, 1948 & minimum $H^{\prime}=0$, higher $H^{\prime}=$ higher values \\
\hline & Evenness & E & Pielou, 1975 & range $0-1 ;$ minimum $E=0$, maximum $E=1$ \\
\hline Vertical diversity & Arten-profil index & $A$ & Pretzsch, 2006 & $\begin{array}{l}\text { range 0-1; balanced vertical structure } A<0.3 \text {; } \\
\text { selection forest } A>0.9\end{array}$ \\
\hline Structure differentiation & $\begin{array}{l}\text { Diameter dif. } \\
\text { Height dif. }\end{array}$ & $\begin{array}{l}T M_{d} \\
T M_{h}\end{array}$ & Füldner, 1995 & $\begin{array}{c}\text { range } 0-1 \text {; low } T M<0.3 \text {; very high differentiation } \\
\qquad M>0.7\end{array}$ \\
\hline \multirow[t]{2}{*}{ Horizontal structure } & $\begin{array}{l}\text { Index of non-ran- } \\
\text { domness }\end{array}$ & $\alpha$ & Mountford, 1961 & mean value $\alpha=1$; aggregation $\alpha>1$; regularity $\alpha$ \\
\hline & Aggregation index & $R$ & Clark \& Evans, 1954 & $\begin{array}{c}\text { mean value } R=1 \text {; aggregation } R<1 \text {; regularity } R \\
>1\end{array}$ \\
\hline Total diversity & Stand diversity & $B$ & $\begin{array}{c}\text { Jaehne \& Dohrenbus- } \\
\text { ch, } 1997\end{array}$ & $\begin{array}{c}\text { monotonous structure } B<4 \text {; uneven structure } B= \\
6-8 \text {; very diverse structure } B>9\end{array}$ \\
\hline
\end{tabular}


firstly individually cross-dated using statistical tests in the PAST 2.17 application (C) 1999-2010 Hammer \& Harper) and consequently subjected to visual inspection according to Yamaguchi (1991). Missing tree rings were replaced by rings $0.01 \mathrm{~mm}$ wide. The PRPs curves were subsequently detrended in the standard way and remodeled into an average treering series in the program ARSTAN. The 30 years spline was applied (Grissino-Mayer et al., 1992). An analysis of negative significant years in terms of radial growth was carried out according to Schweingruber, et al. (1990). Each extremely thin tree ring, not reaching $40 \%$ of the diameter average of previous four years, was tested as significant. A negative year was confirmed if such a strong increment reduction occurred at least in $20 \%$ of trees on the plot. Finally, average tree-ring series in correlation with climate data (monthly precipitations and temperatures in the period 1976-2014) was modeled using software DendroClim (c 1994-2002 DendroLab).

Statistical analyses were processed in the Statistica 12 software (@ 1984-2013 StatSoft). Data were log transformed to acquire normal distribution (tested by Kolmogorov-Smirnov test). The differences in annual ring width of trees and defoliation of trees between individual PRPs and time periods of research (before and after symptoms of ash disease) were tested by one-way analysis of variance (ANOVA) and consequently by post-hoc Tukey's HSD tests. Variances are shown by standard deviation ( \pm SD). Unconstrained principal component analysis (PCA) in Canoco 5.03 program (C 1997-2013 Microcomputer
Power) was used to analyse relationships between stand characteristic, health status, diversity, climate data and site parameters in order to reveal similarity of all records. Data were log-transformed, centred and standardized before the analysis. The results of the PCA analysis were visualized in the form of an ordination diagram.

\section{Results}

\section{Production and structure of tree layer}

In 2015 the number of live trees with $\mathrm{DBH} \geq 5$ $\mathrm{cm}$ ranged between 484-920 trees ha ${ }^{-1}$ (184-440 ash trees $\mathrm{ha}^{-1}$ ) with SDI $0.75-0.91$, which indicates a decrease in numbers by $9.6 \% \pm 2.8 \mathrm{SD}$ for all trees and $15.2 \% \pm 3.8 \mathrm{SD}$ for ash tree over the period of 6 years (Tab. 3). Overall, the largest decrease in numbers of ash trees was observed on waterlogged PRP 39 (19.3\%) and PRP 60 (18.3\%), the lowest on PRP 42 $(9.8 \%)$. The stand volume was $371-601 \mathrm{~m}^{3} \mathrm{ha}^{-1}$, out of which 97-375 $\mathrm{m}^{3} \mathrm{ha}^{-1}$ was European ash in 2015. The largest stand volume, reaching $601 \mathrm{~m}^{3} \mathrm{ha}^{-1}$, was found on PRP 40; the smallest, $371 \mathrm{~m}^{3} \mathrm{ha}^{-1}$, was on PRP 60 . The proportion of ash on PRPs was following: PRP 39 27\%, PRP 40 59\%, PRP 42 48\% and PRP $6054 \%$. The rest of stand volume were admixed tree species (Acer pseudoplatanus L. 3-41\%, Alnus glutinosa L. Moench. 0-33\%, Picea abies /L./ Karst. 0-30\%, Fagus sylvatica L. 0-16\%, Abies alba Mill. 0-5\%, Ulmus glabra Huds. 0-5\% and others less than 2\%). Over 6

Table 3. Overview of basic stand characteristic of permanent research plots

\begin{tabular}{|c|c|c|c|c|c|c|c|c|c|c|c|c|c|}
\hline PRP & year & $\begin{array}{c}\mathrm{t} \\
(\mathrm{y})\end{array}$ & $\begin{array}{l}\mathrm{dbh} \\
(\mathrm{cm})\end{array}$ & $\begin{array}{c}\mathrm{h} \\
(\mathrm{m})\end{array}$ & $\mathrm{f}$ & $\begin{array}{c}\mathrm{V} \\
\left(\mathrm{m}^{3} \text { trees }^{-1}\right)\end{array}$ & $\begin{array}{c}\mathrm{N} \\
(\text { trees ha-1) }\end{array}$ & $\begin{array}{c}\mathrm{G} \\
\left(\mathrm{m}^{2} \mathrm{ha}^{-1}\right)\end{array}$ & $\begin{array}{c}\mathrm{V} \\
\left(\mathrm{m}^{3} \mathrm{ha}^{-1}\right)\end{array}$ & h:dbh & $\begin{array}{c}\text { PAI } \\
\left(\mathrm{m}^{3} \mathrm{ha}^{-1} \mathrm{y}^{-1}\right)\end{array}$ & $\begin{array}{c}\text { MAI } \\
\left(\mathrm{m}^{3} \mathrm{ha}^{-1} \mathrm{y}^{-1}\right)\end{array}$ & $\begin{array}{c}\text { TVP } \\
\left(\mathrm{m}^{3} \mathrm{ha}^{-1}\right)\end{array}$ \\
\hline \multicolumn{14}{|c|}{ European ash } \\
\hline \multirow{2}{*}{39} & 2009 & 77 & 23.2 & 17.60 & 0.570 & 0.424 & 228 & 9.6 & 97 & 75.9 & 1.0 & 1.26 & 97 \\
\hline & 2015 & 82 & 25.5 & 19.36 & 0.536 & 0.530 & 184 & 9.4 & 97 & 75.9 & 0.8 & 1.23 & 101 \\
\hline \multirow{2}{*}{40} & 2009 & 79 & 34.2 & 31.17 & 0.426 & 1.220 & 324 & 29.8 & 395 & 91.1 & 3.5 & 5.00 & 395 \\
\hline & 2015 & 83 & 35.7 & 31.84 & 0.421 & 1.341 & 280 & 28.0 & 375 & 89.2 & 3.5 & 4.93 & 409 \\
\hline \multirow{2}{*}{42} & 2009 & 58 & 26.7 & 20.04 & 0.408 & 0.458 & 488 & 27.3 & 224 & 75.1 & 3.8 & 3.86 & 224 \\
\hline & 2015 & 62 & 28.2 & 21.07 & 0.400 & 0.526 & 440 & 27.4 & 231 & 74.7 & 3.8 & 3.85 & 239 \\
\hline \multirow{2}{*}{60} & 2009 & 96 & 30.2 & 19.06 & 0.428 & 0.585 & 416 & 29.7 & 243 & 63.1 & 2.8 & 2.53 & 243 \\
\hline & 2015 & 101 & 32.7 & 19.58 & 0.424 & 0.697 & 340 & 28.4 & 236 & 59.9 & 2.5 & 2.51 & 254 \\
\hline \multicolumn{14}{|c|}{ Total } \\
\hline \multirow{2}{*}{39} & 2009 & 94 & 25.4 & 16.67 & 0.671 & 0.566 & 876 & 44.4 & 496 & 65.6 & 6.8 & 5.28 & 496 \\
\hline & 2015 & 98 & 26.7 & 17.70 & 0.649 & 0.643 & 804 & 44.9 & 517 & 66.3 & 6.3 & 5.34 & 523 \\
\hline \multirow{2}{*}{40} & 2009 & 79 & 32.9 & 26.09 & 0.526 & 1.168 & 532 & 45.2 & 621 & 79.3 & 6.5 & 7.86 & 621 \\
\hline & 2015 & 83 & 34.0 & 26.33 & 0.530 & 1.267 & 484 & 43.9 & 613 & 77.4 & 6.0 & 7.80 & 647 \\
\hline \multirow{2}{*}{42} & 2009 & 57 & 24.8 & 17.75 & 0.459 & 0.394 & 1012 & 49.1 & 398 & 71.6 & 9.0 & 6.98 & 398 \\
\hline & 2015 & 61 & 26.2 & 19.01 & 0.448 & 0.459 & 920 & 49.7 & 423 & 72.6 & 8.8 & 7.11 & 434 \\
\hline \multirow{2}{*}{60} & 2009 & 86 & 28.0 & 18.11 & 0.475 & 0.530 & 700 & 43.2 & 371 & 64.7 & 6.3 & 4.31 & 371 \\
\hline & 2015 & 90 & 29.7 & 18.62 & 0.476 & 0.614 & 616 & 42.7 & 378 & 62.7 & 6.0 & 4.40 & 396 \\
\hline
\end{tabular}

Notes: PRP permanent research plot, $t$ average age of stand, $d b h$ mean breast height diameter, $h$ mean stand height, $f$ form factor, $v$ mean tree volume, $N$ number of trees per ha, $G$ stand basal area, $V$ stand volume, $h: d b h$ slenderness ratio, $P A I$ periodic annual increment; MAI mean annual increment, TVP total volume production. 


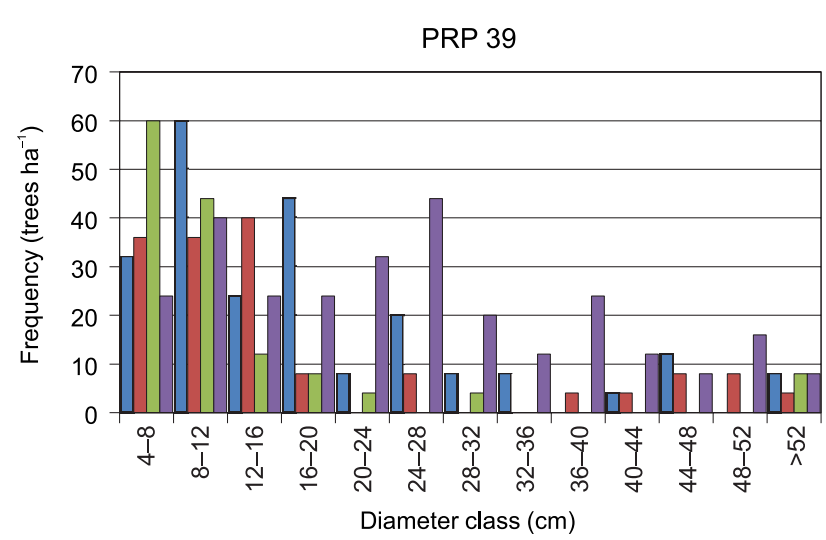

$\square$ Fraxinus excelsior

$\square$ Fagus sylvatica

$\square$ Acer pseudoplatanus

$\square$ Alnus glutinosa

PRP 42

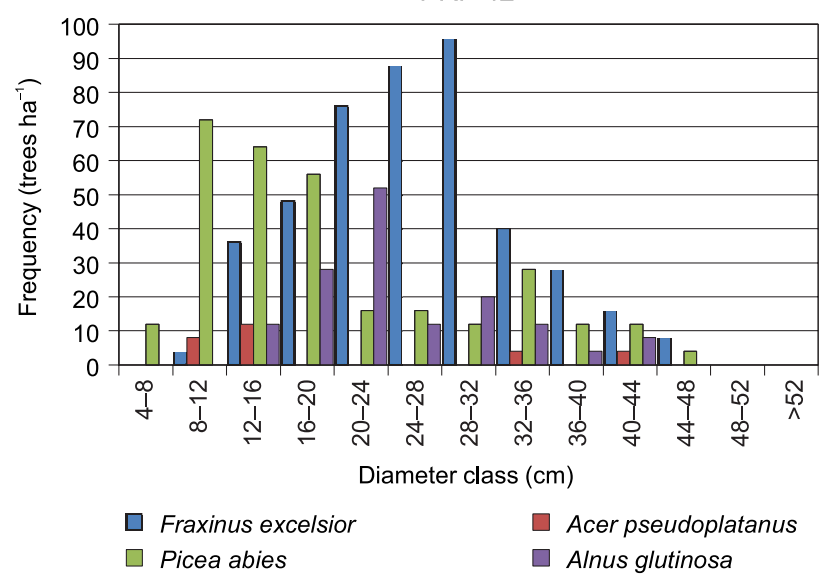

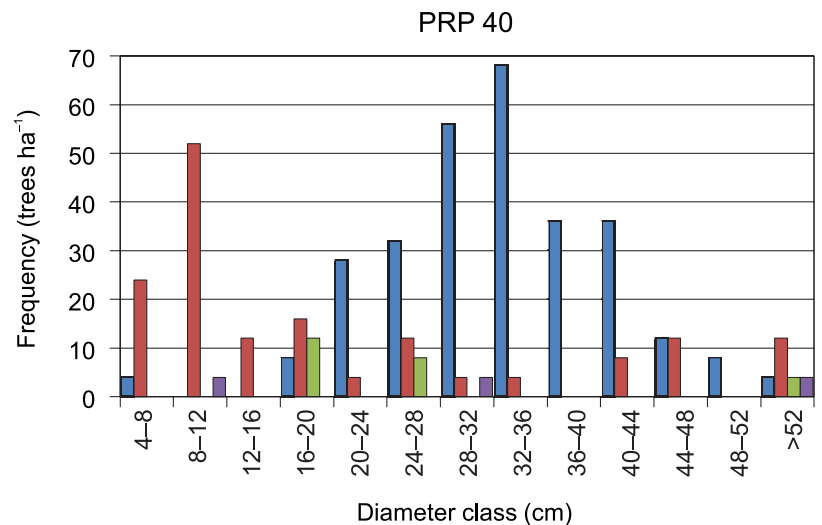

$\square$ Fraxinus excelsior

$\square$ Abies alba

$\square$ Acer pseudoplatanus

$\square$ Fagus sylvatica

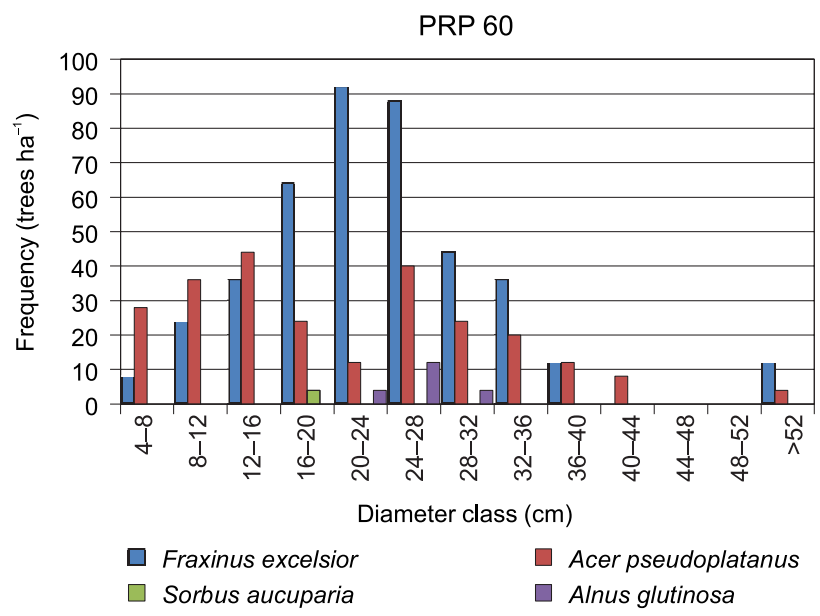

Fig. 2. Histogram of diameter classes by species in the mixed stands on permanent research plots

years stand volume indicated an increase by $2.8 \% \pm$ $2.8 \mathrm{SD}$, while stand volume of ash decreased by $2.7 \%$ \pm 2.8 SD. In 2015, periodic annual increment of the stand ranged between $6.0-8.8 \mathrm{~m}^{3} \mathrm{ha}^{-1} \mathrm{y}^{-1}\left(0.8-3.8 \mathrm{~m}^{3}\right.$ $\mathrm{ha}^{-1} \mathrm{y}^{-1}$ for ash) and mean annual increment 4.4-7.8 $\mathrm{m}^{3} \mathrm{ha}^{-1} \mathrm{y}^{-1}\left(1.2-4.9 \mathrm{~m}^{3} \mathrm{ha}^{-1} \mathrm{y}^{-1}\right.$ for ash). The stand basal area fluctuated between $42.7-49.7 \mathrm{~m}^{2} \mathrm{ha}^{-1}(9.4-$ $28.4 \mathrm{~m}^{2} \mathrm{ha}^{-1}$ for ash).

The stands are composed mainly of two or three layers with variously differentiated vertical canopy. In 2015 the crown closure ranged between 0.75-0.91 and the crown projection area per ha between 2.10 3.17. Detected fungi caused canopy decrease by $6.4 \% \pm 1.8 \mathrm{SD}$, respectively by $15.2 \% \pm 8.4$ SD during the study period. The largest decrease in crown projection area was observed on PRP 60 (26.2\%).

In the whole investigated area, the trees reached average DBH $26.2-34.0 \mathrm{~cm}$; in case of European ash, it was $25.5-35.7 \mathrm{~cm}$. On PRP 39, the second thinnest diameter class $8-12 \mathrm{~cm}$ prevailed (Fig. 2). The thicker the diameter class, the lower the representation. On PRP 40, 42 and 60 medium diameter classes 20.1-36 cm occurred most frequently. Over 6 years $72 \%$ of dead ash trees belonged to diameter classes to $20 \mathrm{~cm}$ and any new ash individual did not grown up from natural regeneration into first tree diameter classes.

The tallest ashes reached $39 \mathrm{~m}$; other admixed species: black alder 23 m, sycamore maple 36 m, European beech $38 \mathrm{~m}$ and Norway spruce $27 \mathrm{~m}$. The living crown height of ash was very variable. In the low tree layer was usually between 4-10 m and 8-22 $\mathrm{m}$ in the upper layer. In 2009 the mean crown length reached $12.6 \mathrm{~m}$, in 2015 the length was by $4.5 \%$ shorter.

\section{Diameter growth dynamics}

Comparing all plots in the studied area of Krkonoše, the mean annual radial increment differed significantly between plots $\left(\mathrm{F}_{(3,108)}=2.8, \mathrm{p}<0.05\right)$; the significantly highest diameter increment was on PRP 60 (2.7 $\left.\mathrm{mm} \mathrm{y}^{-1} \pm 0.6 \mathrm{SD}\right)$ as opposed to other plots. The lowest diameter increment was on PRP 42 (2.1 $\left.\mathrm{mm} \mathrm{y}^{-1} \pm 0.4 \mathrm{SD}\right)$, followed by PRP 40 (2.5 $\left.\mathrm{mm} \mathrm{y}^{-1} \pm 0.5 \mathrm{SD}\right)$ and PRP $39\left(2.6 \mathrm{~mm} \mathrm{y}^{-1} \pm 0.6 \mathrm{SD}\right)$. Differences of mean annual diameter increments on PRPs was observed at age $30\left(\mathrm{~F}_{(3,108)}=19.9, \mathrm{p}<\right.$ 


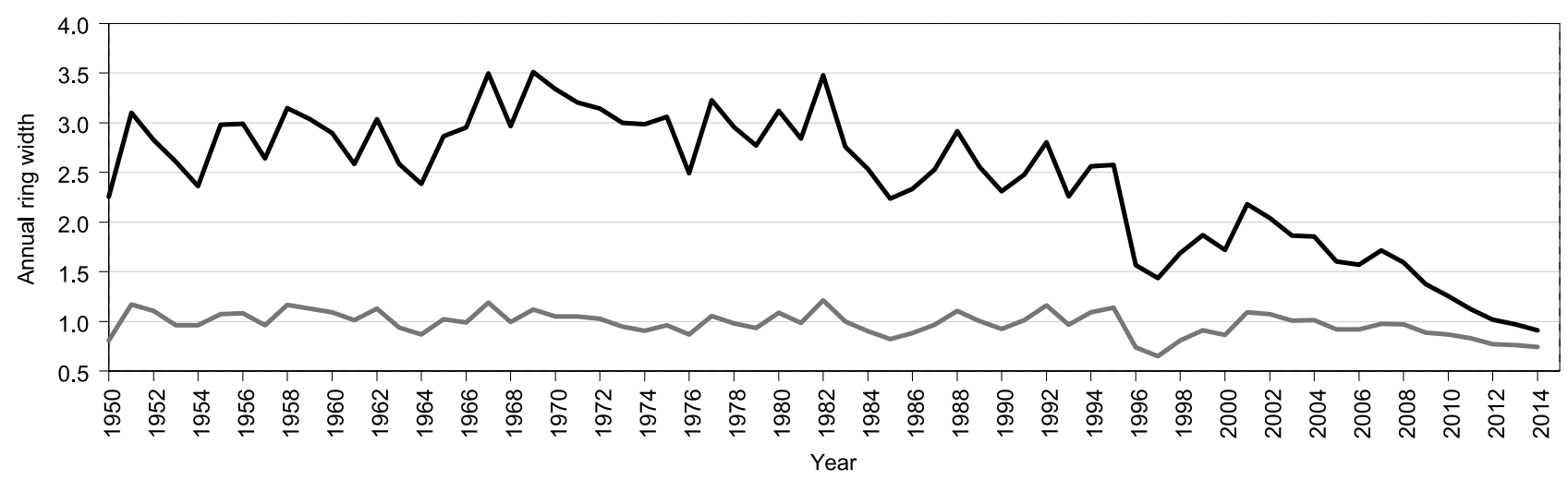

Fig. 3. Mean tree-ring curve of European ash in mm (black line) and standardized ring-width chronologies after age detrending (gray line) in the Krkonoše Mts.

$0.001)$, but there was similarity of increments at age $50\left(\mathrm{~F}_{(3,98)}=1.0, \mathrm{p}>0.05\right)$.

A comparison of mean tree ring curves for each PRP shows an apparent similarity among them (t-test >3.4) that it was possible to make a local standard chronology for stands with significant admixture ash in the Krkonoše Mts. The largest fluctuation of standardized ring-width chronologies was found on PRP 60 ( \pm 0.16 SD) since 1965.

In Fig. 3, the regional standard tree-ring chronology clearly shows radial increment on the ash PRP in the Krkonoše region in 1950-2014. A significant decrease (negative years) of radial increment in all chronologies occurred in 1985, 1996 and 1997 (Fig. 4 ), related to very low temperatures (strong frost) at the beginning of the year. The period of continuous decrease of radial increment of trees infested by $H$. fraxineus started in the 2007. Comparing standardized ring-width after age detrending before and after this year, significantly lower diameter increment was observed after year $2007\left(\mathrm{~F}_{(1,254)}=22.3, \mathrm{p}<0.001\right)$.

Correlation between ash diameter increment and monthly temperature for all PRPs was generally the strongest one (compared to precipitation) and showed several significant values $(\alpha=0.05)$. Diameter increment in 1976-2014 in Krkonoše positively

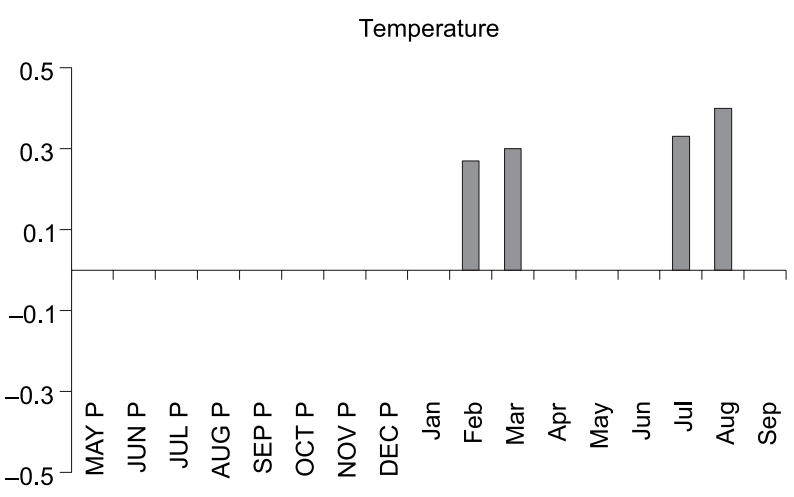

correlated with the average temperature in February, March, July and August of the particular year $(\mathrm{r}=$ $0.27,0.30,0.33$ and 0.40 ). In addition, radial growth positively correlated with the amount of precipitation in December of previous year $(r=0.28)$ and March of the particular year $(r=0.26$; Fig. 4). In contrast, on waterlogged PRP 39 and 60 the positive dependence of radial growth on average monthly precipitation was not statistically significant, there was negative effect of precipitation in June of previous year $(\mathrm{r}=$ $0.30)$ respectively.

\section{Biodiversity of tree layer}

The vertical structure was moderately or even highly diversified in 2015, as confirmed by the Arten-profil index $(A=0.48-0.69$; Tab. 4$)$. The average differentiation of the structure was medium $\left(T M_{d}=\right.$ $0.32-0.41)$, similarly like the height differentiation on PRP $40\left(\mathrm{TM}_{\mathrm{h}}=0.34\right)$, even small on others plots $\left(T M_{h}=0.22-0.29\right)$. The crown differentiation (part of $B$ index) was mainly medium $(K=1.60-3.34)$. In terms of species diversity, richness index showed high values on PRP $60(D=0.59)$, respectively very high richness was observed on others PRPs $(D=$ $0.73-0.85)$. Species heterogeneity was medium to

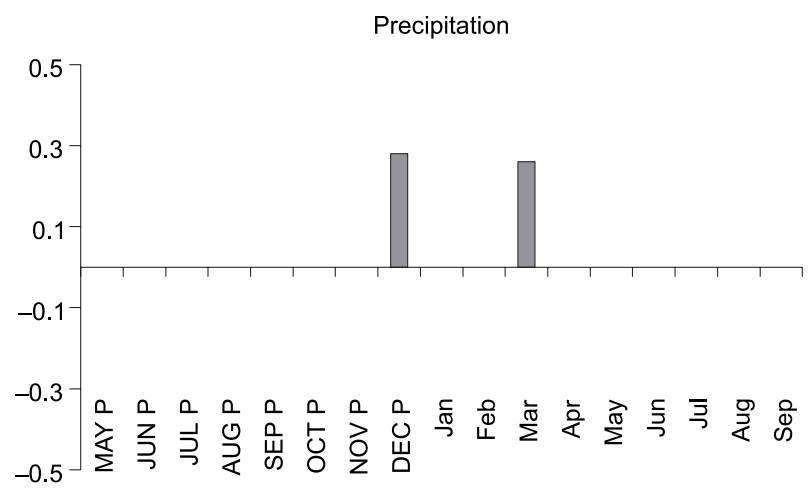

Fig. 4. Significant values $(\alpha=0.05)$ of correlation coefficients of regional residual index tree-ring chronology with average monthly precipitation and temperature from May of previous year (capital letters) to August of the current year (normal letters) in question in the period 1976-2014 
Zdeněk Vacek et al.

Table 4. Stand biodiversity indices of mixed stands on permanent research plots

\begin{tabular}{cccccccccccc}
\hline PRP & year & $\mathrm{D}$ & $\mathrm{H}^{\prime}$ & $\mathrm{E}$ & $\mathrm{A}$ & $\mathrm{TM}_{\mathrm{d}}$ & $\mathrm{TM}_{\mathrm{b}}$ & $\alpha$ & $\mathrm{R}$ & $\mathrm{B}$ \\
\hline \multirow{2}{*}{39} & 2009 & 0.886 & 0.663 & 0.785 & 0.725 & 0.395 & 0.317 & $1.382^{*}$ & $0.870^{*}$ & 10.263 \\
& 2015 & 0.852 & 0.633 & 0.749 & 0.685 & 0.375 & 0.289 & $1.391^{*}$ & $0.844^{*}$ & 9.683 \\
& 2009 & 0.797 & 0.427 & 0.549 & 0.492 & 0.412 & 0.346 & 1.096 & 1.060 & 7.729 \\
40 & 2015 & 0.769 & 0.421 & 0.541 & 0.481 & 0.408 & 0.336 & 1.128 & 1.081 & 7.363 \\
& 2009 & 0.723 & 0.487 & 0.626 & 0.659 & 0.329 & 0.259 & 1.104 & 1.019 & 8.776 \\
42 & 2015 & 0.733 & 0.490 & 0.630 & 0.664 & 0.318 & 0.236 & 1.208 & 1.004 & 8.148 \\
& 2009 & 0.763 & 0.345 & 0.443 & 0.529 & 0.360 & 0.238 & $1.591^{*}$ & 0.916 & 9.656 \\
& 60 & 2015 & 0.592 & 0.334 & 0.479 & 0.513 & 0.348 & 0.225 & $1.702^{*}$ & 0.928 & 8.970 \\
\hline
\end{tabular}

Notes: $D$ species richness index, $H^{\prime}$ species heterogeneity index (entropy), $E$ species evenness index, $A$ Arten-profil index, $T M_{d}$ diameter differentiation index, $T M_{h}$ height differentiation index, $\alpha$ non-randomness index, $R$ aggregation index, $B$ total diversity index; ${ }^{*}$ statistically significant at level 0.05 (horizontal structure $-\alpha, \mathrm{R}$ ).
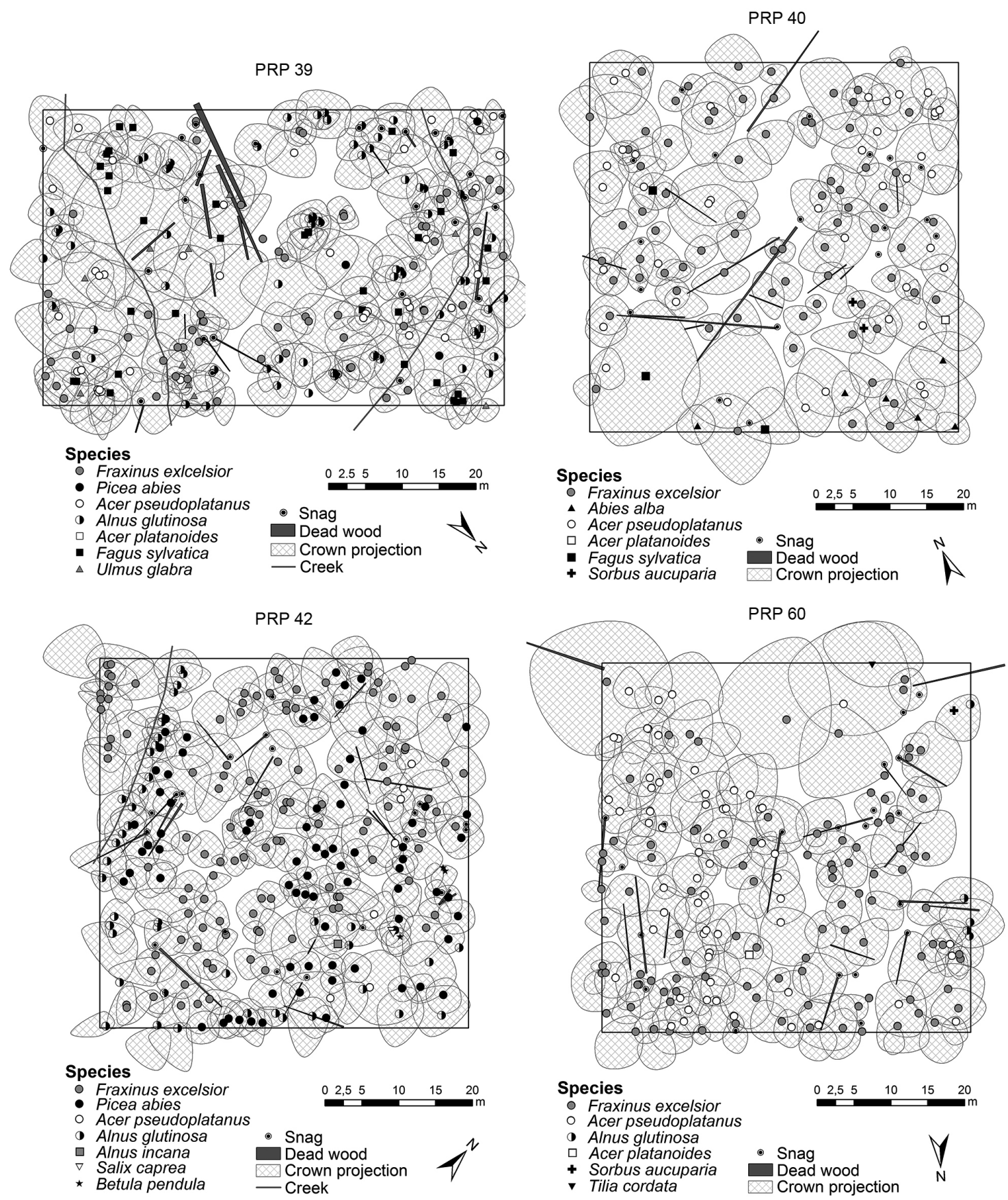

Fig. 5. Horizontal structure of ash stands on PRP 39, 40, 42 and 60 
Table 5. Mean annual defoliation (\%) of European ash on permanent research plots in the Krkonoše Mts. in 2009-2015

\begin{tabular}{ccccccccc}
\hline PRP & Type trees & $2009 / 10$ & $2010 / 11$ & $2011 / 12$ & $2012 / 13$ & $2013 / 14$ & $2014 / 15$ & Total \\
\hline \multirow{2}{*}{39} & all & 4.6 & 1.3 & 2.9 & 5.8 & 4.4 & 7.6 & 26.6 \\
& live & 2.9 & -0.4 & 1.2 & 4.5 & 3.1 & 3.7 & 15.1 \\
40 & all & 0.9 & 1.6 & 2.8 & 3.2 & 7.3 & 11.9 & 27.7 \\
& live & 0.9 & 0.7 & 2.0 & 2.4 & 2.8 & 7.6 & 16.4 \\
42 & all & 0.8 & 0.5 & 1.5 & 3.3 & 4.6 & 4.1 & 14.6 \\
& live & 0.0 & 0.5 & 1.5 & 2.5 & 3.2 & 1.9 & 9.6 \\
60 & all & 0.1 & 1.4 & 2.3 & 1.7 & 6.0 & 10.1 & 21.6 \\
& live & 0.1 & 0.6 & 1.5 & 0.9 & 2.0 & 8.7 & 13.7 \\
\hline
\end{tabular}

high $\left(H^{\prime}=0.33-0.63\right)$ and species evenness was predominantly high $(E=0.48-0.75)$. The total stand diversity according to $B$ index showed an uneven structure on PRP $40(B=7.36)$, diverse structure on PRP 42 and PRP $60(B=8.15-8.97)$ and even a highly varied structure on PRP $39(\mathrm{~B}=9.68)$.

Over 6 years, the largest decrease in diversity was observed on PRP 39 (5.5\%) totally through all indices, the lowest on PRP 42 (2.3\%). In more details, the largest decrease in diversity (without aggregation indices) was observed by species $D$ index $(7.1 \% \pm$ 9.0 SD), particularly on PRP 60 (22.4\%), followed by $T M_{h}$ index $(6.5 \% \pm 2.5 \mathrm{SD})$. In contrast, the increase
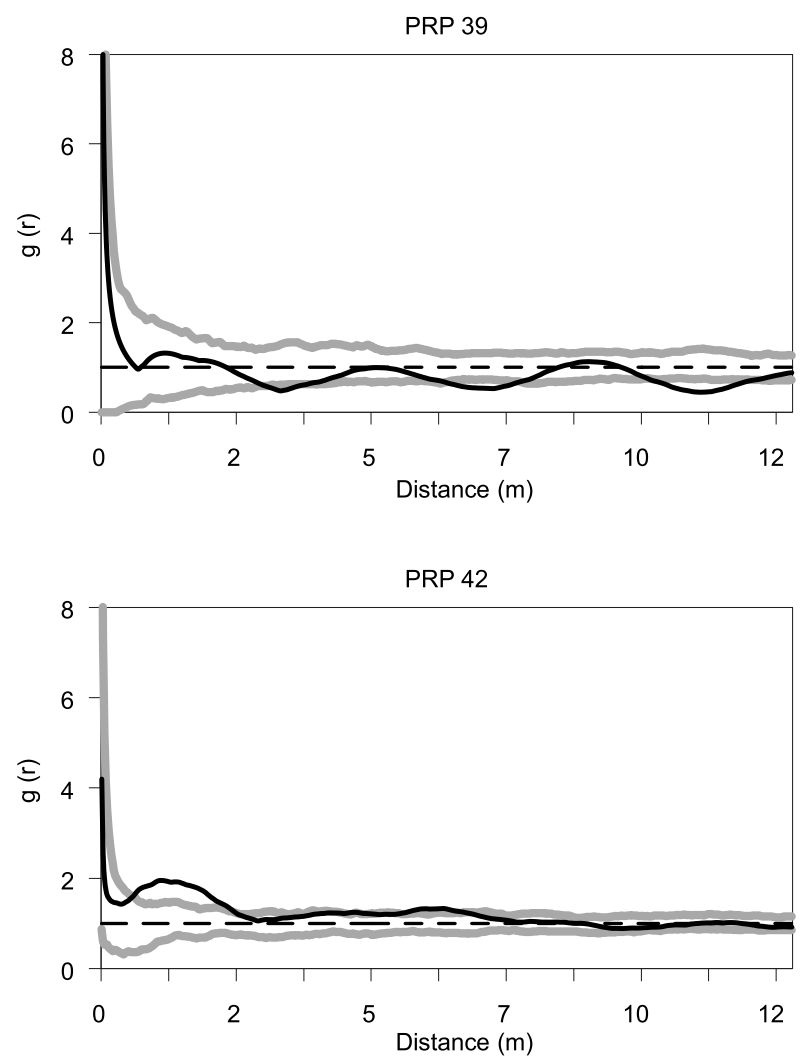

in diversity was observed only by species $E$ index $(0.6 \% \pm 4.7$ SD), particularly on PRP $60(8.1 \%)$.

In terms of both surveyed structural indices, the trees of the tree layer on PRP 39 grew significantly in clusters (Fig. 5, Tab. 4). On PRP 40 and 42 the indices show mainly random structure of the trees in the tree layer. On PRP 60, the trees were clustered; only $R$ index indicated random structure. Prevailing random structure of trees, as apparent from the distances among them, was documented by Ripley's $L$-function on PRPs. Only on PRP 39 and on PRP 60, spatial pattern was aggregated at spacing up to $3 \mathrm{~m}$, respectively between 6 to $10 \mathrm{~m}$.
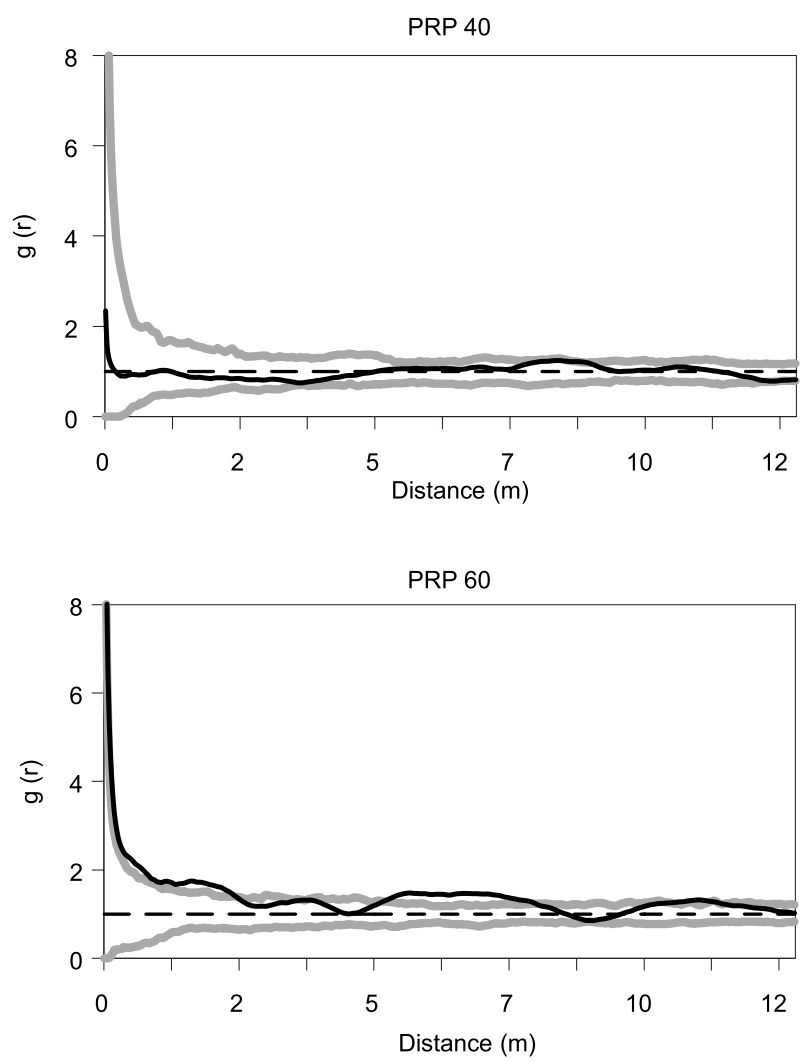

Fig. 6. Relationship between horizontal structures of ash trees without dieback symptoms and trees infected by $H$. fraxineus on permanent research plots expressed by pair cross correlation function; the bold black line represents the pair cross function for real distances of trees; the dashed black line on the level of $g(r)=1$ represents the mean course for random spatial distribution of trees and the two gray curves represent $95 \%$ interval of reliability; if the observed value (black line) exceeds the upper (respectively lower) limit of the simulation interval, it indicates significant aggregation - positive relationship between two tested groups (respectively inhibition - negative relationship) 
Horizontal structure of ash trees according to surveyed structure indices indicated that trees on PRP 39 and 42 showed aggregation structure, on PRP 40 and 60 indices implied cluster to random structure. In contrast, in case of European ash, clustery structure in stands mildly prevailed. On PRP 39, though, with spacing over $7.5 \mathrm{~m}$ random structure prevailed, on PRP 42 randomness prevailed with spacing up to $1 \mathrm{~m}$, and $5.5 \mathrm{~m}$ on PRP 60. In terms of relationship between horizontal structures of healthy looking trees and trees infected by fungus $H$. fraxineus, pair cross correlation function showed on plots at high altitude (PRP 42, 60) positive relationship at distances to $7 \mathrm{~m}$; in other cases, spatial pattern of ash trees was predominantly random, such as on PRP 39 and 40 (without interaction; Fig. 6).

\section{Health status of stands}

The mean annual defoliation of all trees was significantly lower in 2009-2010 than 2014-2015 $\left(\mathrm{F}_{(1,698)}=\right.$ 108.2, $\mathrm{p}<0.001)$, respectively the mean defoliation of all live trees $\left(\mathrm{F}_{(1,654)}=69.3, \mathrm{p}<0.001\right)$. In the first half of the surveyed period, the average annual defoliation of all ash trees (live + dead) ranged between 0.9-2.9 $\%$, and $0.6-1.3 \%$ in case of live trees (Tab. 5). In the latter half of the period, we observed a significant increase of defoliation. The average annual defoliation of all ash trees reached $4.0-7.5 \%$ in that period; $2.6-4.3$ $\%$ in live trees. Despite of the fact that on PRP 40 in 2009-2010 foliage increased in all as well as in live ash trees (by $0.9 \%$ ), in 2014-2015 there was observed the highest defoliation of all PRPs (11.9\% in all trees). In contrast, the lowest defoliation of live trees $(0.0 \%)$ in 2009-2010 was observed on PRP 42 and also in 2014 -2015 the defoliation was the lowest of all plots in both cases ( $4.1 \%$ in all and $1.9 \%$ in live trees). Comparing all plots during investigated period, there was significant difference between the total mean defoliation $\left(\mathrm{F}_{(3,}\right.$ $\left.{ }_{346)}=27.4, p<0.001\right)$. Separately the mean defoliation was significantly lower on PRP 42 (14.6\%) and PRP 60 (21.6\%), opposite on plots characterized by low altitude - on PRP 40 (27.7\%) and PRP 39 (26.6\%). At the beginning of the study, very mild defoliation occurred only in suppressed trees with a small and restricted crown. In 2014 and 2015, the fungus $H$. fraxineus caused dieback of dominant trees with the crown restricted from one, two or three directions, respectively regardless of the tree class (coenotic position.)

\section{Relationships among site, stand characteristics, biodiversity and health condition}

The first ordination axis of PCA analysis explains $45.6 \%$, and the first four axes together explain $98.2 \%$

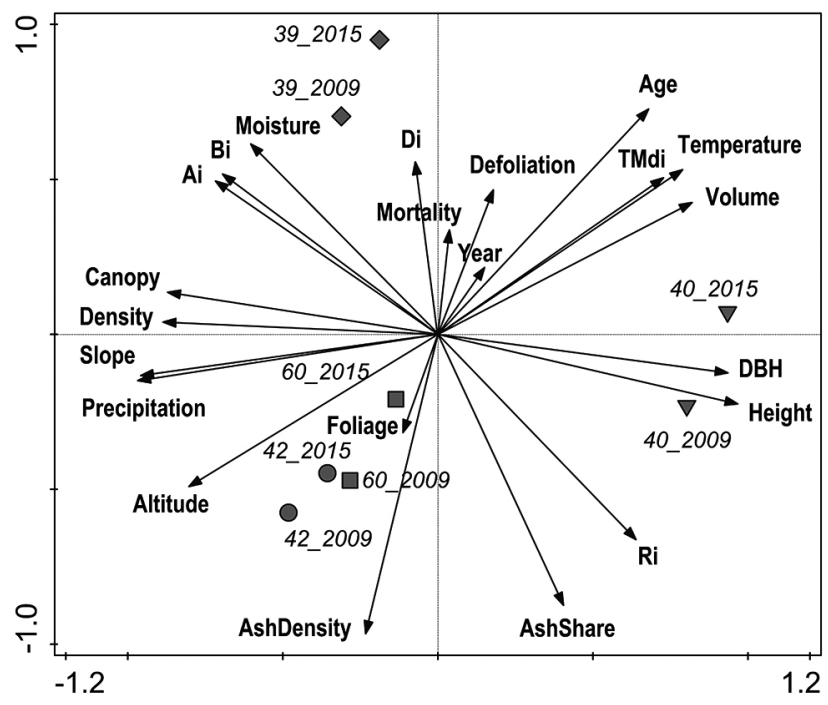

Fig. 7. Ordination diagram showing results of principal component analysis of relationships among plot parameters (Slope, Altitude, Moisture of soil), climatic data (Precipitation, Temperature), stand characteristics (Age mean stand age, $D B H$ quadratic breast diameter, Height mean stand height, Volume of stand, Density of ash/trees, Canopy crown projection areas, Ash share from species composition), health status (Foliage of all ash trees, Defoliation of all ash trees, Mortality of trees), diversity indices (see Tab. 2) and time (Year); Codes: •, $\nabla, \bullet$, $\boldsymbol{\bullet}$ indicate plots with year record (2009-2015)

of the variability in the data (Fig. 7). The first axis $\mathrm{x}$ represents mean $\mathrm{DBH}$, number of all trees, amount of precipitation and canopy. The second axis y represents ash mortality, number of ash in stand and species richness. Altitude was positively correlated with mean foliage of all trees and precipitation, while these parameters were negatively correlated with mean temperature, stand volume, diameter differentiation, mortality and mean defoliation of all trees. Tree mortality, defoliation of trees and mean stand age increased with time, while mean foliage of trees and number of ash trees decreased. Species richness, vertical structure, total diversity and soil moisture were positively correlated to each other, while these parameters were negatively correlated with ash proportion in stand and $R$ aggregation index (tendency to aggregation). Mortality was also closely positively connected with soil humidity. Ash characteristics (volume, share) were independent of trends of characteristics of the whole stand. Mean DBH was positively correlated with height, while these parameters were negatively correlated with stand density and canopy. The dynamics of all parameters during the 6 years was remarkable especially for PRP 40 as marks of each record are relatively distant one from another whereas marks for PRP 42 are the closest together. Plots differed from one another, when PRPs with higher altitude, slope and precipitation $(42,60)$ occupied the left down part of the diagram that is 
characterized by lower stand volume, mortality and defoliation of trees compared with PRP 39 and 40.

\section{Discussion}

Variable stand structures and site conditions were confirmed in the framework of our study as well as studies carried out in other localities. Similar stand and structure characteristics can be found in stands with ash in the Białowieża National Park in Poland where the stand volume reached $500 \mathrm{~m}^{3} \mathrm{ha}^{-1}$ (Faliński \& Pawlaczyk, 1995). Szymura et al. (2010) also presented similar results $\left(526 \mathrm{~m}^{3} \mathrm{ha}^{-1}\right)$ in their study from the foothills of the Sudeten Highlands. Slightly larger stand volume, ranging between $547-591 \mathrm{~m}^{3}$ $\mathrm{ha}^{-1}$, was observed in close to nature forests Fraxino pannonicae-Ulmetum (Janik et al., 2008). In contrast, significantly lower results between $233-347 \mathrm{~m}^{3} \mathrm{ha}^{-1}$ in mixed stands with dominating ash were presented from the foothills of the Italian Alps (Alberti et al., 2009). In ash, similarly as in other species, the diameter increment and crown formation clearly depends on silvicultural conditions (Dobrowolska et al., 2011). Also Juodvalkis et al. (2005) documented in Lithuania, that thinning of stands supports diameter increment of ash, especially in young stands, and the diameter increment positively correlated with the canopy openness at the same time.

Comparing the stand basal area with other studies, it was considerably higher in our case. Szymura et al. (2010) presented $39.4 \mathrm{~m}^{2} \mathrm{ha}^{-1}$, Alberti et al. (2009) stated the maximum stand basal area from five surveyed plots $32.0 \mathrm{~m}^{2} \mathrm{ha}^{-1}$ and $32.3 \mathrm{~m}^{2} \mathrm{ha}^{-1}$ was documented from the Rhine valley (Trémolières et al., 1998). In favourable conditions on rich soils, the ash can reach up to $40-50 \mathrm{~m}$ and DBH $160-180 \mathrm{~cm}$ (Marigo et al., 2000; Dobrowolska et al., 2011), but usual height is $20-25 \mathrm{~m}$ (Collin \& Badot, 1997). The tallest ash trees $(>40 \mathrm{~m})$ in close-to-natures forests were observed in Slovakia - Hrončokovský grún̆ locality (Holeksa et al., 2009). No individual on our PRPs exceeded $40 \mathrm{~m}$, though several trees got close.

The significantly highest mean annual diameter growth was on PRP $60(2.7 \mathrm{~mm})$ as opposed to the lowest diameter increment on PRP $42(2.1 \mathrm{~mm})$. Ash productivity is strongly influenced by soil composition, climate factors and silviculture. Species thrives on rather deep, humid, fertile, heavy and partially decalcified soils (Střeštík \& Šamonil, 2006; Dobrowolska et al., 2011). In term of climatic factors, correlation was generally the strongest between ash increment and temperature compared to precipitation on study plots, especially in the winter and second half of growing season. A similar response to climate was found also in the Lithuania, where strong limiting factor were low temperatures during winter
(Karpavičius \& Vitas, 2006). In the Krkonoše Mts. these strong frost in winter caused a significant decline in the diameter increment in 1985 and 1996. The early-wood of ash responds positively to air temperatures and precipitation in winter. The amount of precipitation has positive effect on the latewood growth (Karpavičius \& Vitas, 2006). On the other hand, the occurrence of fungi pathogens is not so frequent in high mountain areas, where annual temperatures are lowest (Kowalski et al., 2016). Global warming probably would increase their pathogenic role in European ash stands (Thompson et al., 2010; Kowalski et al., 2016).

At present, ash is significantly compromised by chronic fungal pathogen $H$. fraxineus that is considered to be the most common origin of the ash dieback in all Europe (Kowalski, 2006; Bakys et al., 2009; Pautasso et al., 2013; Mitchell et al., 2014; Adamčíková et al., 2015). Changes in stand productions, biodiversity and health condition for the Krkonoše Mts. indicated a negative development of ash health status in the period 2009-2015. During 6 years, the number of ash trees indicated the decrease by $15.2 \%$. Stand volume reflected decrease of ash volume reaching $2.7 \%$. The largest decrease in production parameters of ash tree was observed on waterlogged PRP 39 and PRP 60 (characterized by rich diameter structure and large amount of ash trees in understory), in contrast to the lowest decrease on PRP 42. In 2009-2015, the mean annual defoliation of ash reached $2.7 \%$ in case of live trees and $4.6 \%$ in all trees and annual deterioration of crown projection canopy reached to $2.5 \%$. Totally defoliation was $13.7 \%$ in living trees and $22.6 \%$ in all trees. Slightly lower annual damage dynamics of crown reducing $2.7 \%$ (2011-2013) was observed from ash alluvial stands in North Bohemia (Havrdová et al., 2014).

On study PRPs, the infection of ash trees started to manifest itself by wilted leaves, dark brown leafstalk necrosis, fall of green leaves, primary shoots dieback and occurrence of large proportion of epicormic shoots (Kowalski, 2001; Thomsen et al., 2007). Mortality was firstly observed in trees with suppressed and sub-dominant growth, therefore, considerable decrease of $T M_{h}$ index was observed in 2015. This fact was also confirmed by Skovsgaard et al. (2010). Later in our study (2014), dominant trees began to be affected too. Fungus was also more common in younger ash stands in western Hungary (Koltay, 2012). Moreover, on our study PRPs the deterioration of health status, such as biodiversity, was relatively higher on the sites more influenced by soil moisture. Similarly, other studies (Koltay, 2012; Havrdová et al., 2014) reported the positive effect of humidity or water on spreading of fungi. Stands with higher altitude and homogenous slopes are also less affected (Havrdová et al., 2014). Study of 17 ash 
provenances showed, that the provenances from altitudes above $600 \mathrm{~m}$ a.s.l. were less affected by the pathogen than those from lower areas (Havrdová et al., 2016). Similarly, decrease in foliation (14.6\%) and biodiversity $(2.3 \%)$ was significantly lower compared to other plots on PRP 42 characterized by high altitude, but also by low groundwater depth and the lowest species richness and diameter differentiation among all plots.

In general, silvicultural treatments can contribute to the situation improvement. In stands with a large infestation of $H$. fraxineus it is necessary to replace pure ash stands by mixed forest (Skovsgaard, 2013). It is recommended to gradually reduce the share of this species in the stands with a dominant ash, especially in areas with humid microclimate (Havrdová \& Černý, 2013). This is connected with the need to increase the share of alternative tree species, including Quercus robur L., Acer pseudoplatanus L., Populus spp., Prunus padus L., etc. (Havrdová et al., 2014; Mitchell et al., 2014). Silvicultural efforts are needed to concentrate primarily on young stands (Skovsgaard et al., 2010). Our results showed, that strongly suppressed individuals should be eliminated in those infected stands, which are very susceptible to this disease. In ash stands with enough healthy trees, the trees infected by fungus $H$. fraxineus should be removed, primary trees with crown defoliation greater than $50 \%$ (Skovsgaard, 2013; Longauer, 2015). Selection of vital trees prefers relatively resistant trees originating from the local environmental conditions (McKinney et al., 2011; Lobo et al., 2014). Provenance trials of F. excelsior showed important differences in the level of resistance to pathogen, but main source of resistance is at the individual genotype level (Havrdová et al., 2016).

\section{Conclusion}

European ash represents a very important tree species in the mixed forests of lower montane areas of the Krkonoše National Park, despite considerable lack of silvicultural care in the past. Nowadays, these forests became priority sites within Natura 2000. The question arises of their stability in the future, as symptoms of the fungus $H$. fraxineus have been occurring more frequently in the last decade. On presented study plots, this fungus caused significant deterioration in growth, foliage, canopy and biodiversity. First symptoms of ash dieback were reflected on suppressed trees and subsequently on trees regardless of the tree class. The infection, defoliation and mortality progressed during the study period. Our results still document considerable production potential of the studied plots. The fungal infestation was positively correlated with soil humidity and negatively correlated with the altitude. However, case study and high heterogeneity of study plots must be considered when interpreting the results. Considering the current lack of effective methods for reducing ash dieback to ecologically tolerable levels, it is necessary to find effective methods for the protection of ash stand in relation to global climatic changes. Strong systematic thinning aimed at supporting target trees should be applied such as preventive protection. Recommendations for active forest management are based on the removal of trees with reduced foliage, the selection of vital trees with resistant genotype, replacing of pure ash stands with mixed forest and using a healthy reproductive material in ash plantations.

\section{Acknowledgments}

The paper was supported by Ministry of Agriculture of the Czech Republic (project NAZV QJ1320122) and Internal Grant Agency, Faculty of Forestry and Wood Sciences, Czech University of Life Sciences in Prague (IGA no. B08/15).

\section{References}

Adamčíková K, Kádasi-Horáková M, Jankovský L \& Havrdová L (2015) Identification of Hymenoscyphus fraxineus, the causal agent of ash dieback in Slovakia. Biologia 70: 559-564.

Alberti G, Peressotti A, Piussi P \& Zerbia G (2009) Structure and stand development of secondary forests in Eastern Prealps (Italy). Dendrochronologia 27: 173-181.

Bakys R, Vasaitis R, Barklund P, Ihrmark K \& Stenlid J (2009) Investigations concerning the role of Chalara fraxinea in declining Fraxinus excelsior. Plant Pathology 58: 284-292.

Bobbink R, Hornung M \& Roelofs JGM (1998) The effects of air-borne nitrogen pollutants on species diversity in natural and semi-natural European vegetation. Journal of Ecology 86: 717-738.

Čermák P \& Mrkva R (2006) Effects of game on the condition and development of natural regeneration in the Vrapač National Nature Reserve (Litovelské Pomoraví). Journal of Forest Science 52: 329-336.

Chytrý M, Kučera T, Kočí M, Grulich V \& Lustyk P (2010) Katalog biotopů České republiky. Ed. 2. Agentura ochrany prírody a krajiny ČR, Praha, Czech Republic.

Clark PJ \& Evans FC (1954) Distance to nearest neighbor as a measure of spatial relationship in populations. Ecology 35: 445-453.

Collin P \& Badot PM (1997) Le point des connaissances relatives a la croissance et au developpe- 
ment du Frêne commun (Fraxinus excelsior L.). Acta Botanica Gallica 144: 253-267.

Dal Maso E \& Montecchio L (2014) Risk of natural spread of Hymenoscyphus fraxineus with environmental niche modelling and ensemble forecasting Technique. Forest Research 3: 131.

Dobrowolska D, Hein S, Oosterbaan A, Wagner S, Clark J \& Skovsgaard JP (2011) A review of European ash (Fraxinus excelsior L.): implications for silviculture. Forestry 84: 133-148.

Dufour S \& Piégay H (2008) Geomorphological controls of Fraxinus excelsior growth and regeneration in floodplain forests. Ecology 89: 205-215.

Duval AV (1987) La régénération naturelle du Frêne (Fraxinus excelsior L.): aspects qualitatifs et quantitatifs. Mémoire de DEA, Univ. Nancy I \& U.E.R. Physique-Chimie-Biologie, France.

Ellenberg H (2010) Vegetation Mitteleuropas mit den Alpen in ökologischer, dynamischer und historischer Sicht. Stuttgart UTB, Germany.

Enderle R, Peters F, Nakou A \& Metzler B (2013) Temporal development of ash dieback symptoms and spatial distribution of collar rots in a provenance trial of Fraxinus excelsior. European Journal of Forest Research 132: 865-876.

Faliński JB \& Pawlaczyk P (1995) Zarys ekologii. Jesion wyniosły Fraxinus excelsior L. (ed. by W Bugała) Instytut Dendrologii, Kórnik, Poznań, pp. 302-334.

Ferrazzini D, Monteleone I \& Belletti P (2007) Genetic variability and divergence among Italian populations of common ash (Fraxinus excelsior L.). Annals of Forest Science 64: 159-168.

Fraxigen (2005) Ash species in Europe: biological characteristics and practical guidelines for sustainable use. Oxford Forestry Institute, University of Oxford, UK.

Füldner K (1995) Strukturbeschreibung in mischbeständen. Forstarchiv 66: 235-240.

Grissino-Mayer HD, Holmes RL \& Fritts HC (1992) International tree-ring data bank program library: user's manual. Laboratory of Tree-Ring Research, University of Arizona, Tuscon, USA.

Goberville E, Hautekèete N-C, Kirby RR, Piquot Y, Luczak C \& Beaugrand G (2016) Climate change and the ash dieback crisis. Scientific Reporst 6: 35303.

Havrdová L \& Černý K (2013) Nekróza jasanu - přehled současných znalostí. Zpravodaj ochrany lesa 17: 54-60.

Havrdová L, Zábranský P \& Černý K (2014) Extrémní rozvoj nekrózy jasanu $\mathrm{v}$ břehových porostech je podmíněn vysokou vlhkostí jejich prostředí. Vodní Hospodářství 64: 1-4.

Havrdová L, Novotná K, Zahradník D, Buriánek V, Pešková V, Šrůtka P \& Černý K (2016) Differences in susceptibility to ash dieback in Czech prove- nances of Fraxinus excelsior. Forest Pathology 46: 281-288.

Hofmeister J, Mihaljevič M \& Hošek J (2004) The spread of ash (Fraxinus excelsior) in some European oak forests: an effect of nitrogen deposition or successional change? Forest Ecology and Management 203: 35-47.

Holeksa J, Saniga M, Szwagrzyk J, Czerniak M, Staszyńska K \& Kapusta P (2009) A giant tree stand in the West Carpathians - an exception or a relic of formerly widespread mountain European forests? Forest Ecology and Management 257: 1577-1585.

Jaehne S \& Dohrenbusch A (1997) Ein verfahren zur beurteilung der bestandesdiversität. Forstwissenschaftliches Centralblatt 116: 333-345.

Janik D, Adam D, Vrška T, Hort L, Unar P, Král K, Samonil P \& Horal D (2008) Tree layer dynamics of the Cahov-Soutok near-natural floodplain forest after 33 years (1973-2006). European Journal of Forest Research 127: 337-345.

Jönsson MT \& Thor G (2012) Estimating coextinction risks from epidemic tree death: affiliate lichen communities among diseased host tree populations of Fraxinus excelsior. PLoS One 7: e45701.

Juodvalkis A, Kairiukstis L \& Vasiliauskas R (2005) Effects of thinning on growth of six tree species in north-temperate forests of Lithuania. European Journal of Forest Research 124: 187-192.

Karpavičius J \& Vitas A (2006) Influence of environmental and climatic factors on the radial growth of European ash (Fraxinus excelsior L.). Ekologija 1: $1-9$.

Kenderes K, Mihok B \& Standovar T (2008) Thirty years of gap dynamics in a central European beech forest reserve. Forestry 81: 111-123.

Klika J (1941) Rostlinosociologická studie křivoklátských lesů. Věstník Královské české společnosti nauk, Praha.

Korpel' S (1995) Die urwälder der Westkarparten. Gustav Fischer, Stuttgart.

Kerr G \& Cahalan C (2004) A review of site factors affecting the early growth of ash (Fraxinus excelsior L.). Forest Ecology and Management 188: 225234.

Koltay A, Szabo I \& Janik G (2012) Chalara fraxinea incidence in Hungarian ash (Fraxinus excelsior) forests. Journal of Agricultural Extension and Rural Development 4: 236-238.

Kowalski T (2001) O zamieraniu jesionów. Trybuna Leśnika 4: 6-7.

Kowalski T (2006) Chalara fraxinea sp. nov. associated with dieback of ash (Fraxinus excelsior) in Poland. Forest Pathology 36: 264-270.

Kowalski T, Kraj W \& Bednarz B (2016) Fungi on stems and twigs in initial and advanced stages of dieback of European ash (Fraxinus excelsior) in 
Poland. European Journal of Forest Research 135: 565-579.

Kirisits T, Kritsch P, Krauml K, Matlakova M \& Halmschlager E (2012) Ash dieback associated with Hymenoscyphus pseudoalbidus in forest nurseries in Austria. Journal of Agricultural Extension and Rural Development 4: 230-235.

Landolt J, Gross A, Holdenrieder O \& Pautasso M (2016) Ash dieback due to Hymenoscyphus fraxineus: what can be learnt from evolutionary ecology? Plant Pathology 65: 1056-1070.

Le Goff NL, Ottorini J-M \& Ningre F (2011) Evaluation and comparison of size-density relationships for pure even-aged stands of ash (Fraxinus excelsior L.), beech (Fagus silvatica L.), oak (Quercus petraea Liebl.), and sycamore maple (Acer pseudoplatanus L.). Annals of Forest Science 68: 461-475.

Lobo A, Hansen JK, McKinney LV, Nielsen LR \& Kjær ED (2014) Genetic variation in dieback resistance: growth and survival of Fraxinus excelsior under the influence of Hymenoscyphus pseudoalbidus. Scandinavian Journal of Forest Research 29: 519-526.

Longauer R (2015) Ash dieback and silviculture strategies for managing infected ash stands: review: Proceedings of Central European Silviculture, 2-4 September 2015, Sborník příspěvků, Brno, Czech Republic.

Lorenz M (1995) International co-operative programme on assessment and monitoring of air pollution effects on forests - ICP forests. Water Air and Soil Pollution 85: 1221-1226.

Margalef R (1958) Information theory in ecology. General Systematics 3: 36-71.

Marigo G, Peltier JP, Girel G \& Pautou G (2000) Success in the demographic expansion of Fraxinus excelsior L. Trees 15: 1-13.

Matisons R, Inohosa LG \& Laiviņš M (2016) Pointer years in tree-ring width of European ash with different crown condition and their relationships with climatic factors in Latvia. Proceedings of the Latvian Academy of Sciences. Section B 70: 116-123.

Matuszkiewicz JM (2008) Zespoły leśne Polski. PWN, Warszawa, Poland.

McKinney LV, Nielsen LR, Hansen JK \& Kjær ED (2011) Presence of natural genetic resistance in Fraxinus excelsior (Oleraceae) to Chalara fraxinea (Ascomycota): an emerging infectious dinase. Heredity 106: 788-797.

McKinney LV, Nielsen LR, Collinge DB, Thomsen IM, Hansen JK \& Kjær ED (2014) The ash dieback crisis: genetic variation in resistance can prove a long term solution. Plant Pathology 63: 485-499.

Mitchell A (1974) A field guide to the trees of Britain and Northern Europe. London, William Collins, UK.
Mitchell RJ, Beaton JK, Bellamy PE, Broome A, Chetcuti J, Eaton S, Ellis CJ, Gimona A, Harmer R, Hester AJ, Hewison RL, Hodgetts NG, Iason GR, Kerr G, Littlewood NA, Newey S, Potts JM, Pozsgai JM, Ray D, Sim DA, Stockan JA, Taylor AFS \& Woodward S (2014) Ash dieback in the UK: a review of the ecological and conservation implications and potential management options. Biological Conservation 175: 95-109.

Mountford MD (1961) On E. C. Pielou's index of non-randomness. Journal of Ecology 49: 271-275.

Nárovec V, Trejtnarová J \& Jančařík V (2008) Čeká jasany chřadnutí? Lesu zdar (Hradec Králové) 14: 4-6.

Neuhäuslová Z \& Káňa K (1999) Mokřadní a pobřežní křoviny a lesy: Péče o chráněná území II. Lesní společenstva (ed. by I Míchal \& V Petř́iček) Praha, Czech Republic.

Oberdorfer E (1953) Der europäische Auenwald. Beiträge zur naturkundlichen Forschung in Südwestdeutschland 12: 23-69.

Orlikowski LB, Ptaszek M, Rodziewicz A, Nechwatal J, Thinggaard K \& Jung T (2011) Phytophthora root and collar rot of mature Fraxinus excelsior in forest stands in Poland and Denmark. Forest Pathology 41: 510-519.

Pautasso M, Aas G, Queloz V \& Holdenrieder O (2013) European ash (Fraxinus excelsior) dieback A conservation biology challenge. Biological Conservation 158: 37-49.

Petráš R \& Pajtík J (1991) Sústava česko-slovenských objemových tabuliek drevín. Lesnícky časopis 37: 49-56.

Pielou EC (1975) Ecological diversity. New York: Wiley, USA.

Pretzsch H (2006) Wissen nutzbar machen für das management von waldökosystemen. Allgemeine Forstzeitschrift/Der Wald 61: 1158-1159.

Rackham O (2014) The ash tree. Dorset: Little Toller, UK.

Scherrer D, Bader MKF \& Körner C (2011) Drought-sensitivity ranking of deciduous tree species based on thermal imaging of forest canopies. Agricultural and Forest Meteorology 151: 1632-1640.

Schröder T \& Dujesiefken D (2001) Typische schadsymptome an baumarten: Krankheitenund schäden der esche. AFZ - Der Wald 56: 276-279.

Schweingruber FH, Eckstein D, Serre-Bachet F \& Bräker OU (1990) Identification, presentation and interpretation of event years and pointer years in dendrochronology. Dendrochronologia 8: 8-38.

Shannon CE (1948) A mathematical theory of communications. Bell System Technical Journal 27: $379-423$.

Skovsgaard JP (2013) How does ash dieback influence silviculture? How can silviculture influence ash 
dieback?: Living with ash dieback in continental Europe: present situation, longterm experience and future perspectives. COST Action FP1103 FRAXBACK Meeting with UK \& IE Stakeholders, 29 November 2013, London, UK.

Skovsgaard JP, Thomsen IM, Skovgaard IM \& Martinussen T (2010) Associations of macroscopic symptoms of crown dieback and other major pests and pathogens in even-aged stands of ash (Fraxinus excelsior L.) in Denmark. Forest Pathology 40: 7-18.

Solheim H, Timmermann V, Børja I \& Hietala AM (2011) Yggdrasils helsetilstand - Askeskuddsjuke er på frammarsj. Skogeieren 96: 34-36.

Stoyan D \& Stoyan H (1992) Fraktale formen und punktfelder: methoden der geometrie-statistik. Akademie verlag, Berlin.

Stöhr A \& Lösch R (2004) Xylem sap flow and drought stress of Fraxinus excelsior saplings. Tree Physiology 24: 169-180.

Střeštík S \& Šamonil P (2006) Ecological valence of expanding European ash (Fraxinus excelsior L.) in the Bohemian Karst (Czech Republic). Journal of Forest Science 52: 293-305.

Szymura TH, Buszczak M \& Szymura M (2010) Structure and dynamics of a mature tree stand in submontane alluvial forest of Carici ramotae-Fraxinetum in the Sudety Mts foothills (Lower Silesia, Poland). Dendrobiology 63: 43-51.

Thomsen IM, Skovsgaard JP, Barklund P \& Vasaitis R (2007) Svampesygdom er årsag til toptørre i ask. Skoven 39: 234-236.
Thompson S, Alvarez Loayza P, Terborgh J \& Katul G (2010) The effects of plant pathogens on tree recruitment in the Western Amazon under a projected future climate: a dynamical systems analysis. Journal of Ecology 98: 1434-1446.

Trémolières M, Sánchez-Pérez JM, Schnitzler A \& Schmitt D (1998) Impact of river management history on the community structure, species composition and nutrient status in the Rhine alluvial hardwood forest. Plant Ecology 135: 59-78.

Tollefsrud MM, Myking T, Sønsteb $\varnothing \mathrm{JH}$, Lygis V, Hietala AM \& Heuertz M (2016) Genetic structure in the northern range margins of common ash, Fraxinus excelsior L. PLoS One 11: e0167104.

Vacek S, Hůnová I, Vacek Z, Hejcmanová P, Podrázský V, Král J \& Putalová T (2015) Effects of air pollution and climatic factors on Norway spruce forests in the Orlické hory Mts. (Czech Republic), 19792014. European Journal of Forest Research 134: $1127-1142$.

Weber-Blaschke G, Heitz R, Blaschke M \& Ammer C (2008) Growth and nutrition of young European ash (Fraxinus excelsior L.) and sycamore maple (Acer pseudoplatanus L.) on sites with different nutrient and water statuses. European Journal of Forest Research 127: 465-479.

Yamaguchi DK (1991) A simple method for cross-dating increment cores from living trees. Canadian Journal of Forest Research 21: 414-416. 